\title{
ENTRE HUMANOS E BESTAS: O INSÓLITO FICCIONAL EM THE GREAT GOD PAN E SHAME
}

\section{Resumo}

O objetivo deste artigo é analisar duas obras ficcionais, a novela The Great God Pan, de Arthur Machen, e o romance Shame, de Salman Rushdie, que contêm situações e eventos insólitos, examinando-as de modo a discutir como os elementos fantásticos presentes em ambos os textos relacionam-se ao contexto de produção das obras, ou seja, respectivamente, o século XIX e a segunda metade do século XX. Machen promoveu uma ruptura em relação à tradição das histórias de horror, então em voga, e Rushdie introduziu na literatura pós-colonial indiana características do Realismo Mágico. Temporalmente distantes, as duas obras recorrem a um mesmo artifício, típico da ficção fantástica, a metamorfose de personagens, e, por meio dela, os autores constroem uma crítica subliminar ao sistema político e social dominante em seu tempo.

Palavras-chave: Insólito; Fantástico; Realismo Mágico; Metamorfose

\section{BETWEEN HUMANS AND BEASTS: THE FICTIONAL UNCANNY IN THE GREAT GOD PAN AND SHAME}

\begin{abstract}
The purpose of this article is to analyze two fictional works, Arthur Machen's novella The Great God Pan and Salman Rushdie's novel Shame, which contain unusual situations and events, examining them to discuss how the fantastic elements in both texts relate to the context of production of the works, that is, respectively, the nineteenth century and the second half of the twentieth century. Machen promoted a break with the tradition of horror stories, then in vogue, and Rushdie introduced features of Magical Realism into the Indian Postcolonial Literature. Temporally distant, the two works resort to the same device, typical of fantastic fiction, the metamorphosis of characters, and, through it, the authors build a subliminal criticism of the political and social system dominant in their own time.
\end{abstract}

Keywords: Uncanny; Fantastic

\section{Introdução}

A irrealidade é a única arma com a qual a realidade pode ser desconstruída, para, em seguida, ser reconstruída.

Salman Rushdie, The Location of Brazil, Imaginary Homelands, 1991, Tradução nossa.
O termo "insólito" corresponde ao que é anormal, incomum, extraordinário e ultrapassa os conceitos de realidade, verdade e até mesmo de gênero literário, pois sua presença na narrativa envolve efeitos diferentes, dependendo da época. A presença do insólito na literatura pode ser vista por diferentes prismas, mas passa por três conceitos básicos explicitados por Todorov: o

\footnotetext{
Doutora em Literatura Comparada (UFRJ) e Professora Adjunta da Universidade do Estado do Rio de Janeiro, onde leciona Literaturas de Língua Inglesa. Sua pesquisa de Pós-Doutorado em Literatura Inglesa (UERJ) focalizou as relações entre literatura e memória étnica. Seu campo de investigação atual abrange questões de identidade, estudos culturais e relações entre texto e leitor. E-mail: shirleysgcarr@gmail.com
} 
estranho, o maravilhoso e o fantástico; conceitos estes ligados à reação das personagens e de um leitor implícito a um evento sobrenatural. De acordo com Todorov (1975), o "estranho" caracteriza-se por elementos sobrenaturais que podem ser explicados racionalmente, "mas que, de uma maneira ou de outra, são incríveis, extraordinários, chocantes, singulares, inquietantes, insólitos" (TODOROV, 1975, p.53). O "maravilhoso" provoca a aceitação do sobrenatural pelas personagens e pelo leitor implícito. O "fantástico", por outro lado, localizando-se na fronteira dos dois primeiros, implica a hesitação experimentada pelo leitor e pelas personagens, que, só conhecendo as leis naturais, "devem decidir se o que percebem deriva da realidade tal como ela existe na opinião comum" (TODOROV, 1975, p.41).

A literatura fantástica surgiu de forma a dar uma roupagem nova à abordagem de determinados assuntos que até então constituíam tabu para a sociedade. No entanto, o advento da psicanálise desvelou esses temas ocultos, proferindo um golpe mortal no fantástico em sua concepção tradicional, dando origem a uma versão moderna (CARREIRA, 2010, pp. 103). Segundo Rodrigues (1988), a maioria dos estudiosos considera o nascimento do fantástico entre os séculos XVIII e XIX, tendo seu amadurecimento ocorrido no século XX. Ao final do século XVIII, o fantástico estava associado à presença do sobrenatural, passando a explorar aspectos psicológicos no século XIX, para, finalmente, a partir do século XX, apresentar como característica a incoerência entre elementos do cotidiano.

O insólito ficcional apresenta-se, portanto, em diferentes formas e denominações, além das já mencionadas, como, por exemplo, o realismo mágico, a ficção científica e seus subgêneros, o steampunk ${ }^{1} \mathrm{e}$ o cyberpunk. ${ }^{2}$

Este breve preâmbulo se faz necessário, uma vez que este artigo tem por objetivo analisar a presença do insólito ficcional em duas obras de períodos distintos: The Great God Pan, ${ }^{3}$ de Arthur Machen, publicada em 1895, e Shame, de Salman Rushdie, publicada em 1983. A novela de Machen é considerada como uma obra de transição do período gótico ao moderno na literatura fantástica, contendo as marcas características dessa transição. Shame é um romance da literatura pós-colonial em língua inglesa, que contém traços do realis- mo mágico que caracterizou os primeiros romances de Rushdie. A distância temporal entre as duas obras e o tratamento dado ao insólito constituem o desafio desta análise comparativa.

\section{O insólito e a arquitetura do medo em The Great God Pan}

Todorov referia-se ao romance gótico como "romance negro", cujos elementos visavam despertar medo no leitor. Era um universo ficcional permeado de acontecimentos insólitos, visões fantasmagóricas, seres macabros e locais lúgubres, que tem em The Castle of Otranto (1764), de Horace Walpole, o seu primeiro exemplar, segundo a tradição.

Em The Great God Pan, Machen distancia-se do modelo gótico ao incorporar ao texto sua crença mística de que o mundo ordinário oculta um outro mundo, cujo desvelamento poderia levar ao extremo da loucura, do sexo e à morte. A ficção de Machen, como um todo, revela a luta do autor contra o materialismo científico que predominava em seu tempo, bem como sua visão de que a experiência mística é um instrumento importante para a compreensão do mundo.

Ao contextualizar a história na Inglaterra do século XIX, Machen rompe com os cenários tradicionais da literatura gótica, porém faz com que pulsões ocultas que habitam o imaginário humano coexistam com a ambientação e o puritanismo vitorianos. A história em si gira em torno de um experimento neurológico feito por um certo Dr. Raymond, na certeza de que, ao fazê-lo, proporcionaria à jovem Mary, que serve de cobaia, um vislumbre do mundo espiritual, ao que denominava "a visão do Grande Deus Pã’. Um amigo, Clarke, a contragosto, é convidado a presenciar a experiência, cujo resultado é catastrófico, uma vez que a jovem acorda da breve cirurgia com estertores de pavor, como se tivesse experimentado o maior horror que alguém já pudesse ter sentido, tornando-se, desde então, mentalmente doente.

Anos mais tarde, em Londres, Clarke, que tenta compilar um livro intitulado "Memórias para provar a existência do diabo", lê a narrativa de um amigo, Dr. Phillips, sobre estranhos acontecimentos ligados a uma 
moça adotada, do País de Gales, cujo nome é Helen Vaughan. Segundo depoimentos, um menino, após tê -la visto com um homenzinho na floresta, começara a ter crises histéricas que se agravaram ao deparar-se, alguns dias mais tarde, com a estátua de um fauno em uma casa, o que o levara à total insanidade. Rachel, a filha de um rico lavrador, igualmente, começara a ter um comportamento estranho após tornar-se amiga de Helen, até que um dia, em desespero, revelara à mãe os estranhos acontecimentos dos quais tomara parte na floresta. Pouco depois, a jovem desaparecera sem deixar rastros.

Outra personagem, Villiers, surge na história, narrando a Clarke como encontrara um velho amigo, Charles Herbert, em plena decadência física e mental. Tomado de pavor, Herbert lhe confidenciara ter sido corrompido de corpo e alma por sua esposa, Helen, que, em seguida, desaparecera com tudo o que ele possuía. Villiers mostra a Clarke um retrato da mulher de Herbert, feito por um pintor que vivia na América do Sul, e este percebe tratar-se da mesma pessoa que Phillips mencionara em seu relato. Surpreende-o, no entanto, a semelhança da jovem com a infortunada Mary.

No capítulo seguinte, um narrador onisciente relata a onda de suicídios entre cavalheiros ricos de Londres. Villiers e seu amigo Austin percebem a relação entre esses homens e uma certa Sra. Beaumont, que chegara recentemente da América. Investigando o paradeiro de Helen, descobrem que ela e Mrs Beaumont são a mesma pessoa e que, sendo uma mulher dissoluta, Helen persuadia os homens a ações que os levavam à loucura e à morte. Villiers decide confrontá-la, entregando-lhe uma corda para que se mate, afirmando que, caso se recuse, entregá-la-á à polícia. Ela o faz, mas morre de modo inusitado, pois seu corpo sofre mutações sucessivas, de um gênero a outro, de humana à besta, dissolvendo-se e reconstituindo-se, até extinguir-se por completo. A conclusão da história consiste em fragmentos que elucidam parcialmente os eventos narrados. O primeiro é de um médico que examinara um estranho cadáver e é seguido de dois fragmentos de cartas trocadas entre Clarke e Raymond.

A arquitetura do medo é construída paulatinamente na novela, a começar pela narração do despertar de
Mary, após a cirurgia:

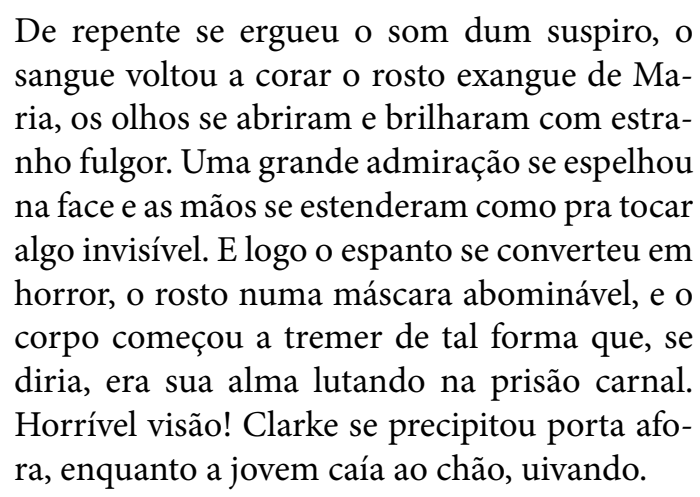

O episódio envolvendo a cabeça da estátua de um fauno estabelece o elo com o título da obra e reporta-se à figura de Pã, divindade filho de Dríope e de Hermes, o mensageiro dos deuses, que nascera com chifres e pernas de bode. Abandonado pela mãe no nascimento, devido à sua aparência, fora, pelo mesmo motivo, proibido por Hermes de chamá-lo de pai. Era temido por quem necessitava atravessar as florestas à noite, pois as trevas e a solidão da travessia causavam pavor, desprovido de causa aparente e atribuído a Pã.

A passagem da novela em que Rachel confessa à mãe o que ocorrera na floresta é suprimida, deixando ao leitor a possibilidade de imaginar o evento:

Numa noite, contudo, depois de Raquel voltar, a mãe ouviu no quarto algo que lhe pareceu um choro abafado. Entrou e encontrou a filha meio despida, sentada na cama, tomada de indizível angústia. Ao ver a mãe, gritou: Ó! Mamã! Por que me deixaste ir com Helena à floresta? Espantada em ver a filha naquele estado, senhora M... a interrogou e Raquel contou uma história terrível. Disse...

Em lugar do relato, surge a fala de Clarke a Phillips:

- Meu Deus! Pensa no que dizes! É monstruoso! Coisas como essa nesta nossa terra, onde o homem vive e morre, luta, triunfa, às vezes sucumbe, é vencido pela tristeza e sofre, vítima de estranhos destinos ao longo de vários anos, bem sei! ... Mas isso, Philips, isso não! Se isso pudesse acontecer, este mundo seria um pesadelo! 
Uma característica marcante da obra é o fato de que o insólito não é introduzido por meio de ações, mas de um conjunto de relatos, interrompidos justamente nas partes em que os fatos geradores do medo deveriam ser expostos. Essa técnica parece fazer parte de um jogo narrativo de exposição e ocultamento que se estende por todo o texto, concretizando no âmbito da arquitetura do texto o tema que a narrativa explora.

Os críticos da época não pouparam Machen, atribuindo-lhe duas falhas na elaboração da novela: sua recusa em descrever os horrores que são sugeridos pelas personagens e o excesso de coincidências. Nenhuma dessas críticas, entretanto, foi capaz de obliterar a maestria de Machen ao construir uma narrativa elaborada para provocar tensão e medo fugindo da obviedade da descrição de fatos.

Outro exemplo significativo é a passagem em que Villiers mostra a Austin um manuscrito:

Olha este belo manuscrito. Foi paginado. Estás vendo? E levei a galanteria a ponto de o atar com fita vermelha. Parecem papéis de negócio. Não parecem? Veja-os bem, Austin. Neles está a descrição das distrações que senhora Beaumont oferecia a seus hóspedes de eleição. $\mathrm{O}$ homem que escreveu isso conseguiu escapar vivo, mas não creio que durante muito tempo. Os médicos acham que deve ter tido um grande abalo.

Austin pegou o manuscrito, mas não leu. Abrindo ao acaso a vista caiu sobre uma palavra, o princípio duma frase, e, com o coração saltando, os lábios brancos e a testa suada, atirou o papel ao chão.

- Toma-o, Villiers, e não me fale mais disso. Raios!, homem. És de pedra? Diabos! Mesmo o medo e o horror à morte ou o pensamento dum homem que será enforcado, no momento em que ouve as sinetas tocando e fica esperando o ruído do patíbulo, nada são comparados a isso. Não quero ler, pois nunca mais conseguiria dormir.

A curiosidade do leitor é atiçada ainda mais após a réplica de Villiers:

- Está bem! Imagino o que leste e sei quão horrível é. Mas, apesar de tudo, é uma velha história, um mistério antigo recuperado em nossa época, com as ruas de Londres substituindo os antigos vinhedos e olivais. Sabemos o que acontecia a quem encontrasse o deus Pã. Os sábios acham que todo símbolo o é duma realidade e não do nada. E era, na verdade, um símbolo bem refinado, esse, sob o qual os antigos velavam as forças secretas e terríveis que se escondem no coração de todas as coisas, perante as quais a alma humana se desvanece e morre, enegrecida, como o corpo ficaria se atacado por correntes elétricas. Essas forças só podem ser nomeadas e concebidas através dum véu que para a maioria não mais é que uma fantasia poética e pra alguns uma história contada por idiotas e loucos. Mas nós, tu e eu, conhecemos um pouco do terror que pode habitar os reinos secretos da vida, sob a aparência da carne. Vimos o informe assumir uma forma.

Embora nenhuma descrição concreta seja oferecida ao leitor, o teor sexual subliminar é evidente.

The Great God Pan deve também a sua notoriedade à implicação religiosa no texto, que pode ser interpretado como uma paródia da história de Cristo, produto da união entre um ser sobrenatural e uma mulher mortal, igualmente denominada Maria. Para os padrões puritanos, a obra era uma blasfêmia, escrita por uma mente pervertida. Essa leitura torna-se possível graças ao fragmento de carta enviada por Raymond a Clarke no último capítulo, no qual ele reconhece o seu erro ao fazer a experiência e admite que Helen Vaughan era a filha de Mary com o deus Pã:

O que eu disse que Maria veria, ela viu, mas me esqueci de que ninguém pode contemplar impunemente o que contemplou. E também esqueci de que uma vez que se abre a casa da vida ela fica acessível àquilo que não podemos nomear e a carne humana pode se tornar o véu do inexprimível. Brinquei com forças desconhecidas e conheces o resultado. Helena Vaughan fez bem em se atar à corda e morrer, por horrível que sua morte tenha sido.

- Aquele rosto enegrecido, aquela metamorfose que se fundia sobre o leito e que, sob nossos olhos, passava de mulher a homem, de homem a besta, e de besta a algo ainda pior, tudo o que testemunhaste, nada me espanta. O que o médico viu já vi, muito antes. Porque compreendi 
minha obra logo no dia em que a criança nasceu. Ainda tinha cinco anos e eu já a vira mais de cem vezes, brincando com o companheiro que sabes quem é. Foi, pra mim, uma angústia indescritível e constante. Alguns anos mais tarde, sentindo que não suportaria mais aquilo, mandei Helena Vaughan a outro lugar. Já sabes o que assustou Trevor no bosque. O resto da história e tudo o que foi descoberto por teu amigo eu já sabia a minha própria custa, do primeiro ao último capítulo. E agora, Helena se reuniu a seus companheiros.

A morte de Helen, filha de uma maléfica emanação do sagrado, precedida de transmutação, é assim descrita no fragmento do Dr. Matheson, responsável pela autópsia:

Se bem que atacado por uma náusea de revolta e quase sufocado pelo odor da corrupção, me mantive firme, privilegiado ou maldito, não sei, olhando o que ali estava, negro como tinta, e que se transformava perante meus olhos. Pele, carne, músculo e osso, e a firme estrutura do corpo humano, tudo o que, até então, considerara algo permanente como o diamante, começou a se fundir e dissolver.

Sabia que agentes exteriores podiam assim devolver o corpo aos elementos mas me recusaria a crer naquilo que via porque havia ali uma força interna que eu não conhecia e que ordenara a dissolução e a metamorfose.

Ali se repetiu, em minha frente, todo o esforço que originou o homem. Vi a coisa vacilar de sexo a sexo, se dividir e se unificar de novo. Vi o corpo regredir às feras que o precederam, o que estava na coroa dos seres descer ao inframundo, ao abismo. Mas o princípio da vida, que cria o organismo, permanecia estável no meio das transformações da forma[...] Eu olhava sempre: Logo nada mais restava além duma substância semelhante a gelatina. E depois a escala foi de novo percorrida, em sentido inverso... (neste ponto são ilegíveis algumas linhas do manuscrito)... instante vi uma forma obscura à minha frente, que não quero descrever. Mas o símbolo pode ser encontrado nalgumas estátuas antigas e naquelas pinturas que sobreviveram à lava, demasiado infames pra que eu fale mais sobre elas......E a indizível aparência, homem e besta, retomou a forma humana. Então a morte sobreveio.

A novela guarda características do fantástico, na medida em que a reação da maioria das personagens, compartilhada com o leitor, é de hesitação em dar credibilidade aos fatos narrados. Apenas as testemunhas da morte de Helen creem na sua veracidade, embora não saibam explicar o que presenciaram.

Apesar das coincidências, fartamente apontadas pelos críticos, Machen construiu em The Great God Pan o embrião de suas futuras publicações e, principalmente, guiou-se pela intuição de que os leitores são capazes de imaginar coisas mais assustadoras do que aquelas que um autor poderia escrever. Ao transferir ao leitor a tarefa de concretizar o elemento causador do medo, ele lhe concede a coautoria, de modo a preencher o espaço lacunar do insólito intuído. Essa habilidade de Machen exerceu grande influência em Lovecraft, que sobre ele afirmou: "Há em Machen um êxtase do medo [grifo nosso] que todos os outros homens são demasiadamente obtusos ou tímidos para capturar, e mesmo Poe não conseguiu prever em toda a sua contundente anormalidade". ${ }^{4}$

\section{O insólito e os meandros da repressão}

A epígrafe deste artigo sugere que, para Salman Rushdie, a irrealidade pode modificar as condições históricas, graças à subversão. Assim, ao se desconstruir o tecido histórico, urdindo sobre ele novo tecido ficcional, permite-se um novo olhar sobre os eventos do passado, ensejando uma reflexão sobre as suas consequências no presente. Em Shame, romance em que o autor reconstitui a história do Paquistão desde sua independência da Índia, em 1947, até a oitava década do século XX, as relações colonizador/colonizado servem de pano de fundo a um estudo sobre os mecanismos de opressão.

Segundo Carreira (2008, p.58),

Uma boa parte dos romances de Salman Rushdie foi construída sobre dois pilares distintos: o realismo mágico e a revisão da história. A opção pelo insólito para reinterpretar os eventos do passado denota a clara intenção do autor de demonstrar a inconfiabilidade dos registros históricos e autobiográficos, pois ambos são permeados pela "verdade da memória" (RUSHDIE, 1991: 25). 
Elementos estilísticos e temáticos do realismo mágico, originariamente associado às literaturas latino -americanas e caribenhas, têm sido empregados contemporaneamente em literaturas pós-coloniais, mais especificamente em obras que trazem em si alguma forma de resistência aos centros imperiais opressivos e seus sistemas totalizantes. Esse fato se verifica não apenas nas ex-colônias inglesas, mas também nas antigas colônias portuguesas.

$\mathrm{Na}$ obra de Rushdie, o realismo mágico se manifesta como a transformação do comum e do cotidiano em uma vivência que inclui experiências sobrenaturais ou fantásticas. Em Gothic-Postmodernism, Maria Beville afirma que

As convenções aceitas aqui como caracterizadoras do surgimento do gótico pós-moderno como um gênero literário novo e distinto incluem: a indefinição das fronteiras que existem entre o real e o imaginário, o que resulta em autoconsciência narrativa e uma interação entre o sobrenatural e a metaficção; uma preocupação com os efeitos sublimes de terror e os aspectos irrepresentáveis da realidade e da subjetividade; dispositivos temáticos góticos específicos de assombração, o doppelgänger, ${ }^{5} \mathrm{e}$ uma filosofia dualista do bem e do mal; uma atmosfera de mistério e suspense e uma função de contranarrativa. [...] [o gótico] funciona para cumprir a expressão da escuridão da pós-modernidade, enquanto os aspectos pósmodernos operam para estabelecer pontos de vista ontológicos e epistemológicos que interrogam as "realidades" éticas e morais aceitas, que têm sido o foco de subversão gótico. [...] Por meio do terror de textos góticos pós-modernos, podemos questionar nossos próprios medos inconscientes, crenças e preconceitos, não só em termos do desejo que os instiga, mas também em termos das repercussões para a sociedade em geral (BEVILLE, 2009, p.18, Tradução nossa).

Muito embora a obra de Rushdie não se enquadre nessa categoria, é relevante a evidência de que textos contemporâneos que recorrem ao fantástico, em suas diversas configurações, dele se servem para promover releituras do tecido social e político contemporâneo.

Shame constitui uma história genealógica que se entrelaça à história do Paquistão por meio de duas per- sonagens rivais, Iskander Harappa e Raza Hyder, que respectivamente são as versões ficcionais de Zulfikar Ali Bhutto, o primeiro presidente após a partição, e do General Zia Ul-Haq que o depôs, tomando o poder. $O$ romance não possui uma figura central dominante, constituindo uma tessitura de histórias cuja espinha dorsal se apoia na relação entre dois conceitos cruciais nas sociedades muçulmanas: izzat e sharam, ou seja, honra e vergonha. Conforme o próprio narrador do romance ${ }^{6}$ explica, izzat corresponde à honra familiar, que só pode ser preservada na medida em que as mulheres experimentem o sentido de sharam, isto é um sentimento de "embaraço, decência, modéstia, timidez, o senso de ter um lugar especifico no mundo" (RUSHDIE, 1983, 33).

Ambos os conceitos refletem o papel subalterno da mulher muçulmana, que, no romance, é a via para a leitura crítica da história oficial, mostrando que o conceito de honra, bem como o de vergonha, assume feições diferentes no universo masculino e no âmbito político.

Em uma entrevista concedida a Una Chaudhuri (1990), Rushdie afirmou que, ao escrever o romance, interessou-lhe a relação entre o sentimento de vergonha e a violência e a eclosão desta como uma força sobre-humana. Ao longo do romance, em meio à rivalidade entre as duas famílias, acontecimentos insólitos ocorrem. O primeiro deles é o nascimento de Sufiya Zinobia, filha do casal Raza e Bilquís Hyder, que, tendo perdido o primeiro filho, desejava que o segundo também fosse um menino.

Devido à decepção que causa aos pais, ela cora ao nascer e a vermelhidão do seu rosto é o primeiro indício das consequências funestas do seu sentimento de inadequação e impropriedade. Bilquís a vê como o "milagre errado", como a lamentável prova de sua incapacidade de dar ao marido o tão sonhado sucessor e quando, aos dois anos de idade, Sufiya contrai uma febre que a afeta mentalmente, em um desabafo, Bilquís confidencia a uma amiga que o marido queria um filho herói e que, no entanto, ela só fora capaz de lhe dar uma filha idiota, uma filha que era a sua vergonha (RUSHDIE, 1983, p. 101).

Conforme Carreira (2008, p. 60), "os traços do realismo fantástico, presentes na obra, e mais especifica- 
mente na transformação de Sufiya Zinobia, introduzem a possibilidade imaginativa do sentimento de vergonha gerar raiva e amor-próprio ao invés de embaraço e honra familiar". Personagem criada a partir de acontecimentos dos quais o autor tomara conhecimento, dentre eles o assassinato de uma jovem pelo próprio pai, paquistanês, sob a alegação de que ela envergonhara a família ao se relacionar sexualmente com um jovem branco, Sufiya concentra em si a vergonha que outros deveriam sentir pelos seus próprios atos. Em uma sociedade sem igualdade de direitos para homens e mulheres, pobres e ricos, o conceito de honra e vergonha é tendencioso e parcial.

À medida que Sufiya cresce, os rubores continuam; a ponto de queimar os lábios da avó que a beija nas faces e as mãos da aia quando esta lhe dá um banho. $\mathrm{O}$ narrador enuncia a sua tentativa de explicação para o fato insólito:

Deixem-me enunciar a minha suspeita: a febre cerebral que tornou Sufiya Zinobia receptiva a tudo o que acontecia à sua volta, também a capacitou para absorver, como uma esponja, uma horda de sentimentos nunca sentidos. Aonde vocês imaginam que eles tenham ido? Eu quero dizer: as emoções que deveriam ter sido sentidas e não o foram, como, por exemplo, o arrependimento por uma palavra dura, a culpa por um crime, o embaraço, a vergonha? (RUSHDIE, 2000, p. 123).?

Essa tentativa, se bem-sucedida, conferiria aos rubores as características do "estranho", isto é, do sobrenatural explicado. No entanto, ela não clarifica os acontecimentos posteriores.

Ao contrário de Helen Vaughan, em The Great God Pan, que exerce intencionalmente uma ação maléfica ${ }^{8}$ no mundo em torno, levando os que com ela se relacionam a um desfecho trágico, Sufiya parece ter duas personalidades: a da jovem mentalmente retardada e inofensiva e a de um monstro interior, capaz de agir vingativamente sempre que o sentimento de vergonha, seu ou de outros, aflora. A ausência de vergonha de seus familiares tem o mesmo efeito sobre ela. Podese perceber nessa dualidade uma versão pós-moderna do conceito de doppelgänger.
Quando percebe que a condescendência de seu pai em relação à viúva Aurangzeb deve-se a um antigo desejo sexual, que traz humilhação à sua mãe, Sufiya libera a sua vergonha sob a forma de uma raiva avassaladora, matando todas as aves que a viúva criava, como é possível observar na citação a seguir:

Sufiya Zinobia, por tanto tempo sobrecarregada com o peso de ser um milagre que dera errado, a personificação da vergonha de uma família, tinha descoberto nos labirintos do inconsciente o caminho oculto que liga sharam à violência; e que, desperta, ela fora tão surpreendida quanto os demais com a força do que havia sido desencadeado. (RUSHDIE, 2000, p.139).

Assim, o narrador se refere ao fato:

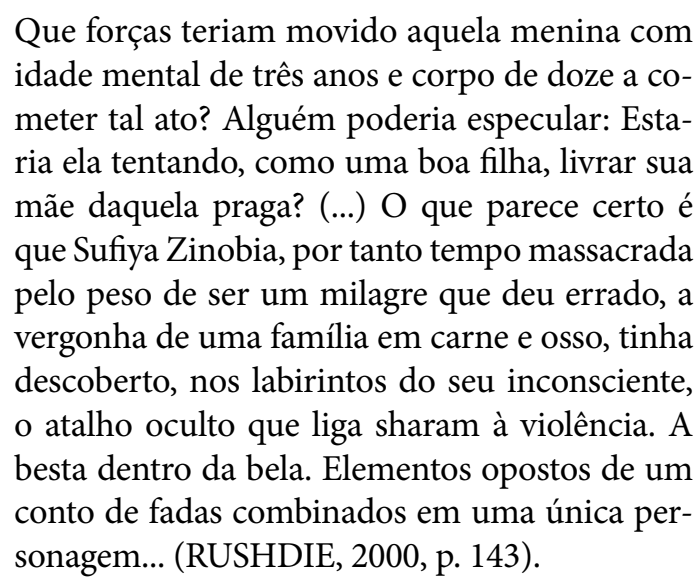

Por essa ocasião, com o corpo tomado de bolhas, rachaduras e tumores, Sufiya é levada ao hospital, onde é atendida por um imunologista de cerca de cinquenta anos: Omar Khayam Shakil, personagem cuja história pessoal é a primeira a ser contada no romance e que fora educado para jamais sentir vergonha. Opostos reunidos, eles terminam por casar-se, apesar da relutância dos pais de Sufiya, devido ao retardamento mental da jovem.

A fera interior surge sempre que Sufiya é exposta a uma situação vexatória, como, por exemplo, quando sua irmã, Good News, para o espanto e humilhação da família, no dia da cerimônia do seu casamento, apresenta o Capitão Talvar Ulhaq como noivo, no lugar da- 
quele cujo nome estava nos proclamas. A sensação de vergonha faz com que Sufiya invista contra o capitão, tentando matá-lo.

Em outro momento, mesmo com sua limitação mental, ela percebe que está sendo traída por Omar, que não se relaciona sexualmente com ela:

Há uma coisa que as mulheres fazem à noite com seus maridos. Ela não o faz, Shahbanou faz isso por ela. (...) Mas ela é uma mulher. Ela tem um marido. Ela não pode resolver isso. A coisa horrível e o sentimento horrível não-fazer -a-coisa. (...) Não há oceano, mas há um sentimento de afundamento. Fá-la doente. Há um oceano. Ela sente sua maré. E, em algum lugar em suas profundezas, uma besta se mexendo. (RUSHDIE, 2000, p. 215).

Quando Omar engravida Shahbanou, Sufiya sai pelas ruas e faz-se violar por quatro rapazes, cujos corpos sem cabeça são encontrados em um lixão. Mais tarde, ao se voltar contra o marido, este a vê debater-se como se estivesse empreendendo uma terrível batalha dentro de si mesma: a luta da mulher, que tenta proteger o homem que ama, com a besta sedenta de sangue.

Ao contrário do que ocorre em The Great God Pan, todos os eventos que envolvem a gradual transformação de Sufiya são explicitamente narrados. Muito embora, não seja o foco desta abordagem, em particular, há uma relação intrínseca entre essas transformações e os demais acontecimentos, de caráter político, no romance. Conforme Newel (1991) afirma, a luta interior da personagem corresponde a uma imagem metafórica do Paquistão; a uma outra batalha que ocorre no plano do real: um passado político que recusa ser esquecido, e que se digladia com o presente:

Rushdie tem domínio do grotesco. Sufiya Zinobia, uma versão fantástica de Dr. Jekyll e Mr. Hyde, funciona como uma imagem metafórica para o Paquistão. [...] Uma criação distorcida de sua mãe mulçumana sonhadora, Bilquis, e de seu pai, Raza, Sufiya simboliza o milagre errado, que é o Paquistão moderno. Rushdie descreve o Paquistão como "um duelo entre duas camadas de tempo, o mundo obscurecido forçando seu caminho de volta através do que lhe fora imposto. O Paquistão, o palimpsesto que se descasca e fragmenta, cada vez mais em guerra consigo mesmo, pode ser descrito como um fracasso da mente sonhadora[...] um milagre que não deu certo" [...]. Como Sufiya, cujas batalhas contra si mesma aumentam à medida que o livro avança, o Paquistão tem "um passado que se recusa a ser suprimido, que batalha diariamente com o presente" (NEWEL, 1991, Tradução nossa).

Ao perceberem que algo de anormal acontece com ela, Omar e Raza decidem drogá-la e mantê-la presa, para que não ofereça perigo a outras pessoas. Porém, no dia em que Raza ordena o assassinato de Iskander Harappa, na prisão, Sufiya desaparece e, em alguns anos, a lenda de uma pantera branca começa a se espalhar.

O desfecho do romance se dá após o encontro final de Omar e Sufiya, entre aquele que nasceu para jamais sentir vergonha e aquela que traz sobre si toda a vergonha do mundo. Ela o mata e, em seguida, entra em combustão, libertando-se do seu fardo:

Ele ficou ao lado da cama e esperou por ela como um noivo na noite de núpcias, enquanto subia em direção a ele, rugindo, como um fogo impulsionado pelo vento. A porta se abriu. E ele na escuridão, ereto, observando o brilho que se aproximava, e então ela estava lá, de quatro, nua, revestida de lama e sangue e merda, com galhos aderindo às suas costas e besouros em seu cabelo. Ela o viu e estremeceu; em seguida, levantou-se sobre as patas traseiras com suas patas dianteiras estendidas e ele teve apenas tempo suficiente para dizer: 'Bem, esposa, então aqui você está finalmente [...] E, em seguida, a explosão vem, uma onda de choque que destrói a casa e, depois disso a bola de fogo do incêndio dela, rolando para fora, para o horizonte como o mar, e por último a nuvem, que se eleva e se espalha e paira sobre a nulidade da cena, até que eu já não possa ver o que não está mais lá; a nuvem silenciosa, na forma de um gigante, o homem cinza e sem cabeça, uma figura de sonhos, um fantasma com um braço levantado em um gesto de despedida. (RUSHDIE, 2000, p. 304) 
O corpo abjeto da pantera branca em que Sufiya se transforma sugere que há duas forças opostas em ebulição dentro dela. Aparentemente, a fera criada pela percepção da hipocrisia social e pelas pressões do instinto, com as quais não saber lidar, predomina, culminando com a morte de Omar. A metamorfose e a monstruosidade, conforme afirma Carreira (2011, p. 60) equivalem a uma forma de empoderamento que ela, como mulher, não pode ter em seu próprio corpo. Entretanto, a incapacidade de a personagem superar seu conflito interior, leva o seu corpo à desintegração.

\section{À guisa de conclusão}

A metamorfose na literatura remonta à literatura latina, tendo como marco as Metamorfoses, de Ovídio, que, ao longo dos séculos, foram frequentemente retomadas com diferentes propósitos. Em The Great God Pan, é possível detectar uma visão particular do autor: galês, criado em Caerleon, cercado por uma paisagem campestre, Macher rejeitava o racionalismo do seu tempo, adotando uma visão mística do entrelaçamento do mundo real com o espiritual.

Machen dizia que a descoberta de uma inscrição em Isca, dedicada a "Nodens, God of the Depths", servira de fonte de inspiração para a sua concepção da novela, e esse fato é mencionado no texto, em um registro atribuído a Clarke.

Os ritos de fertilidade da antiga Roma, a imagem fálica de Pan, são revividos no romance em atos de comunhão psicossexual e em revelações aniquiladoras, que, no entanto, não são desveladas aos olhos do leitor. Muito embora seja perceptível que a concepção de desvio, de transgressão que o insólito sugere em The Great God Pan foi construída em confronto com a concepção cristã de pecado, o episódio da metamorfose de Helen, de um sexo a outro, de humana à besta, no momento de sua morte, epitomiza metaforicamente questões consideradas abomináveis para a sociedade do século XIX, como, por exemplo, o medo, associado à teoria evolucionista, de que, em algum momento, a raça humana entrasse em um processo inverso, ou seja, de degeneração. ${ }^{9}$
A crítica de Stoddard (2008, p.228) ao texto de Machen, em A hideous bit of morbidity: an anthology of horror criticism from the Enlightenment to World War I, demonstra que os contemporâneos de Machen viram na novela o produto de uma mente doentia. Em relação à arquitetura do texto, o excesso de coincidências, que Lovecraft chegou a apontar, colabora para desequilibrar, em alguns momentos, a construção do medo, mas não o suficiente para apagar um aspecto de extrema relevância no tratamento que Machen dá ao texto: o sobrenatural associado ao insólito não narrado, mas implícito.

Shame, por sua vez, como foi demonstrado ao longo deste artigo, contém uma reescrita de acontecimentos relacionados à história política do Paquistão de um ponto de vista crítico, possível graças à escrita peculiar de Rushdie, que entrelaça história, paródia e acontecimentos insólitos. Nesse panorama, as mulheres têm um espaço especial, pois é por meio de suas ações que Rushdie discute como elas são vítimas da ambição, lascívia, fanatismo e crueldade na sociedade islâmica. O narrador/persona de Rushdie afirma que:

\begin{abstract}
Antes de começar, eu achava que tinha nas mãos uma história excessivamente masculina, uma saga de rivalidade sexual, de ambição, poder, patrocínio, traição, morte e vingança. Mas as mulheres parecem ter sobrepujado, saindo das periferias da história para exigir a inclusão de suas próprias tragédias, histórias e comédias, obrigando-me [...] a ver minha trama masculina refratada, por assim dizer, através dos prismas do seu lado invertido e feminino. (RUSHDIE, 2000, p 173).
\end{abstract}

A presença de Sufiya Zinobia, a personagem feminina preponderante no romance, tem assim o seu escopo definido. Ela é a única capaz de uma rebelião bem-sucedida. No entanto, vários críticos, como Ahmad (1992), Cundy (1996) e Grewal (1994), sinalizam que essa é uma liberdade conquistada de uma forma inusitada, por meio da metamorfose em uma besta assassina. Ela se transforma exatamente naquilo que está na origem da mutação: o abuso da mulher.

A violência gerada pela vergonha, no entanto, pode ser interpretada de outra forma, com um teor 
de ordem mais política do que social, representando o modo como forças opressoras podem gerar reações violentas, levando um país ao colapso. Seja como for, o insólito em Shame é de uma ordem diferente daquela que se apresenta em The Great God Pan. Embora a novela de Machen seja, ainda hoje, considerada como um dos grandes exemplos da ficção de horror e o romance de Rushdie tenha sido, de certa forma, rotulado a partir das características do Realismo Mágico, ambos contêm traços do fantástico, pela hesitação e pela ausência de explicação do insólito tanto no universo diegético quanto no dos leitores, implícitos ou empíricos.

\section{Notas}

1. O steampunk é um subgênero da ficção científica que incorpora a tecnologia e design de estética inspirados pelas máquinas a vapor da época da Revolução Industrial, no século XIX.

2. O cyberpunk é um subgênero da ficção científica que mescla ciência avançada, como as tecnologias de informação e a cibernética e algum grau de desintegração ou mudança radical na ordem social, projetando futuros distópicos onde a vida diária é impactada pela rápida mudança tecnológica.

3. Gutemberg, razão pela qual não serão mencionados os números de página. A tradução das citações é de E. Leão Maia.

4. Disponível em : http://www.victoriangothic.org/arthurmachen-an-ecstasy-of-fear/ Acesso em: 03/07/2016.

5. Mito do duplo, originário de lendas germânicas que se reportam a seres sobrenaturais capazes de reproduzir cópias idênticas de ouros seres.

6. O autor/narrador configura-se como uma persona, a versão ficcional do próprio Rushdie.

7. A tradução das citações das obras de Rushdie é da autora do artigo.

8. Maléfica porque leva os demais a uma transgressão que nem eles mesmos nem a sociedade podem suportar.

9. Para uma abordagem mais precisa do tema, sugere-se a leitura da dissertação de Geoffrey Reiter, intitulada 'Man Is Made a Mystery': The Evolution of Arthur Machen's Religious Thought".

\section{Referências}

AHMAD, A. Salman Rishdie's Shame. Postmodern migrancy and the representation of women.In:

In Theory: Classes, Nations, Literatures. London, Verson, 1992.pp. 123-158.

BEVILLE, Maria. Gothic- postmodernism. Voicing the terrors of postmodernity. Amsterdam, New York: Rodopi, 2009.

CARREIRA, Shirley. Relações entre o insólito e os leitores empírico e virtual. Caderno Seminal Digital, Rio de Janeiro, Ano 16, no 14, V. 14, pp. 102-115, Jun.Dez/2010.

Do corpo objeto ao corpo abjeto: escritas contemporâneas do corpo. In: MONTEIRO, Maria Conceição, CHIARA, Ana Cristina, SANTOS, Francisco V. dos (orgs) Escritas do corpo. Rio de Janeiro: Caetés, 2011, pp. 54-62.

O insólito em Shame, de Salman Rushdie. In: GARCIA, Flávio, MICHELLI, Regina, PINTO, Marcello O. Poéticas do Insólito. Conferências e Palestras do III Painel "Reflexões sobre o Insólito na narrativa ficcional": o insólito na literatura e no cinema. Rio de Janeiro: Dialogarts, 2008, pp. 58-63.

CHAUDHURI, Una. Excerpts from a Conversation with Salman Rushdie. In: Imaginative Maps. Volume II, No. 1.New York: Turnstyle Press, 1990. Disponível em: http://www.subir.com/rushdie/uc_maps.html

CUNDY, Catherine. Salman Rushdie. Manchester, New York: Manchester University Press, 1996.

GREWAL, Inderpal. Salman Rushdie: Marginality, Women, and Shame. Reading Rushdie: Perspectives on the Fiction of Salman Rushdie. Ed. D.M. Fletcher. Amsterdam: Rodopi B.V., 1994. 123-144.

MACHEN, Arthur. The Great God Pan. The Project Gutenberg EBook. Disponível em: https://www. gutenberg.org/files/389/389-h/389-h.htm Acesso em 20 de junho de 2016.

.O grande deus Pã. Tradução de E. Leão Maia. Lisboa: Vega, 1986.

NEWEL, Josh. The Grotesque and Post-Colonialism in Shame. 1991. Disponível em: http://www. postcolonialweb.org/pakistan/literature/rushdie/ srgrotesq.html Acesso em 20 de junho de 2016.

REITER, Geoffrey “Man Is Made a Mystery": The Evolution of Arthur Machen's Religious Thought. Dissertation submitted to the Graduate Faculty of Baylor University in Partial Fulfillment of the Requirements for the Degree of Doctor of Philosophy, August, 2010.

RODRIGUES, Selma Calasans. O Fantástico. São Paulo: Ática, 1988. 
RUSHDIE, Salman. Shame: a novel. New York: Picador USA, 2000 [1983].

Imaginary Homelands. Essays and criticism 1981-1991.Londres: Granta Books, 1991.

STODDARD, Robert. [1895] Review of The Great God Pan. In: COLAVITO, Jason. $\boldsymbol{A}$ hideous bit of morbidity: an anthology of horror criticism from the Enlightenment to World War I. Jefferson, North Carolina, London: McFarland \& Company, 2008. 228-230.

TODOROV, Tzvetan. The Fantastic: A Structural Approach to a Literary Genre. Translated by Richard Howard. Ithaca: Cornell University, 1975.

Recebido em: 14/07/2016 Aceito em: 19/08/2016 